Fauziah, Jumiati I Efektivitas Peran Dinas Koperasi dan UMKM Kota Padang dalam Pengembangan Usaha Kecil dan Menengah di Kelurahan Purus Kota Padang

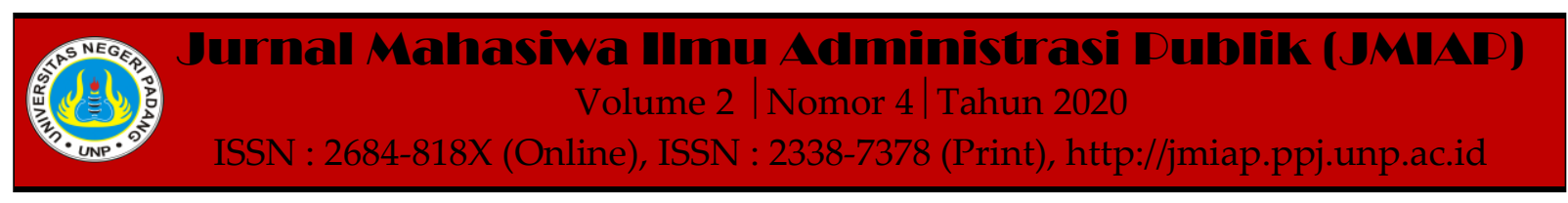

\title{
EFEKTIVITAS PERAN DINAS KOPERASI DAN UMKM KOTA PADANG DALAM PENGEMBANGAN USAHA KECIL DAN MENENGAH DI KELURAHAN PURUS KOTA PADANG
}

\author{
Fauziah $^{1(a)}$, Jumiati $^{2(b)}$ \\ ${ }^{1}$ Jurusan Ilmu Administrasi Negara, Universitas Negeri Padang \\ ${ }^{2}$ Jurusan Ilmu Administrasi Negara, Universitas Negeri Padang \\ a)fauziahhozer@gmail.com, ${ }^{b)}$ jumiati@fis.unp.ac.id
}

\begin{abstract}
This research was conducted at the Department of Cooperatives and UMKM in Padang City. It aims to describe the effectiveness of the role of the Padang City Cooperative and UMKM Service in Small and Medium Enterprise Development in Purus Village, Padang City. The effectiveness of the role has several problems that arise, causing the effectiveness of the role to be disrupted and less than optimal for the Padang City Cooperative and UMKM Office. The problem of role effectiveness continues to increase so that more attention is needed by the Padang City Cooperative and UMKM Office in the effectiveness of its role. This studied use a qualitative methods and descriptive approaches which aims to describe, record, explain, interpret (describe) and describe the effectiveness of the role of the Padang City Cooperative and UMKM Service in Small and Medium Business Development in Purus Village, Padang City. The selection of informants are determined by thecnique purposive sampling.. The types of data are primary and secondary data collected through observation, interviews and documentation study. The data analysis techniques used can be grouped into 3 stages, namely data reduction, data presentation and drawing conclusions. He point of view of this studied is the Implementation of the role of the Padang City Cooperative and UMKM Service in Small and Medium Business Development in Purus Village, Padang City has been effective and well implemented, but has not been in accordance with what is expected of UMKM actors to be given marketing and packaging training for UMKM players. In implementing its role it is less effective due to a lack of budget for developing UMKM in Purus sub-district and not all UMKM get assistance with facilities and infrastructure. External constraints on the Effectiveness of the Role of the Padang City Cooperative and UMKM Service in UMKM Development In Purus Village, Padang City is disturbed by the Covid-19 pandemic which hinders the Role of the Padang City Cooperative and UMKM Office in the Development of UMKM in Purus Village, Padang City.
\end{abstract}

Keywords : Effectiveness, Role and UMKM

Corresponding author. Email.fauziahhozer@gmail.com

How to cite this article. Fauziah \& Jumiati. (2020). Efektivitas Peran Dinas Koperasi dan UMKM Kota Padang dalam Pengembangan Usaha Kecil dan Menengah di Kelurahan Purus Kota Padang. Jurnal Mahasiwa Ilmu Administrasi Publik (JMIAP) Jurusan Ilmu Administrasi Negara Fakultas Ilmu Sosial Universitas Negeri Padang, Volume 2 (4), Hal. 123-133.

http://jmiap.ppj.unp.ac.id

ISSN : 2684-818X (Online), ISSN : 2338-7378 (Print)

Copyright $\odot 2020$. Published by Labor Jurusan Ilmu Administrasi Negara FIS UNP, Padang 


\section{PENDAHULUAN}

Efektivitas ialah sebuah tolak ukur yang menjelaskan seberapa besar sasaran (kualitas, kuantitas, dan waktu) yang telah dicapai. Apabila persentase sasaran yang tercapai semakin, maka semakin besar efektivitas yang diraih (Tiara \& Mardianto, 2019).

Defenisi dari peranan yaitu sekumpulan perilaku oleh seseorang yang dilakukan ketika melakukan suatu kegiatan. Penghargaan yang dimaksud dalam suatu peranan yaitu norma yang bisa memunculkan akibat terjadinya sebuah peranan. Dalam lingkup bahasa organisasi, cara memperoleh suatu peranan diambil dari uraian jabatan. Adapun uraian jabatan yang dimaksud tanggung jawab dan dokumen tertulis yang memuat dan persyaratan atas suatu pekerjaan. Maksud peranan pada hakikatnya adalah sebuah bentuk interaksi antar orang/anggota di sebuah organisasi. Maka banyak yang dapat dilakukan oleh anggota untuk membuat rencana intervensi ke arah perbaikan, perubahan serta ke arah penyempurnaan organisasi (Putra, 2015).

Rencana Strategis dari Dinas Koperasi dan UMKM Kota Padang tahun 20142019 dibuat pada bulan desember tahun 2014. Peran Dinas Koperasi, Usaha Kecil dan Menengah Kota Padang adalah di bidang koperasi, usaha kecil dan menengah mengurus urusan aktivitas pemerintahan, serta tugas perbantuan yang telah diberikan untuk daerah.

Hal ini berarti tugas pokok dari Dinas Koperasi, Usaha Kecil dan Menengah Kota Padang yakni sebuah unsur pelaksana otonomi daerah di bidang koperasi, usaha kecil dan menengah serta sebagai pelaksana tugas perbantuan yang diberikan baik oleh pemerintah pusat (Kementerian Koperasi dan UKM) maupun Pemerintah Propinsi. (Rencana Strategis Dinas Koperasi dan UMKM Kota Padang Tahun 2014-2019).

Usaha mikro kecil dan menengah (UMKM) ialah sebuah bentuk usaha kecil sekelompok masyarakat yang terbentuk menurut inisiatif individu. Hampir kebanyakan masyarakat menganggap bahwa UMKM cuma memakai pihak tertentu saja. Padahal hakikatnya UMKM mempunyai peran penting sekali dalam meminimalisir tingkat pengangguran di Indonesia. (Kurniawan, F. D, 2014).

Pada pasal PERDA Nomor 6 Tahun 2016 menyatakan kedudukan Dinas Koperasi Usaha Kecil dan Menengah menjadi sebuah bagian dari pelaksana Pemerintah Daerah yang dikepalai oleh seorang Kepala Dinas yang memiliki tanggung jawab langsung ke Wali Kota dengan perantara sekretaris daerah. (Rencana Strategis Dinas Koperasi dan UMKM Kota Padang Tahun 2014-2019).

Sebagai pihak yang bertanggung jawab terhadap pemberdayaan dan pengembangan UMKM, Dinas Koperasi dan UMKM Kota Padang juga menemui masalah yang dapat menghambat perkembangan UMKM berdasarkan pelayanan yang diberi Dinas Koperasi dan UMKM Kota Padang yaitu masalah yang dihadapi adalah akses permodalan UMKM masih rendah, Daya saing produk UMKM untuk masuk ke pasar yang lebih luas masih perlu di tingkatkan, Lemahnya manajemen pelaku UMKM khususnya pelaku usaha mikro yang pembukuannya belum terpisah antara rumah tangga dan usaha. (Rencana Strategis Dinas Koperasi dan UMKM Kota Padang tahun 2014-2019).

Pemerintah Daerah beserta Dinas Koperasi dan UMKM bekerjasama untuk mengembangkan kemajuan UMKM dengan pesat. Dari data yang diperoleh di Dinas Koperasi dan UMKM Kota Padang Tahun 2015-2018, mengatakan bahwa terdapat sebanyak 113 UMKM. Berikut ini ialah data dari usaha mikro (UMKM) menurut bentuk usaha yang bisa dilihat di tabel yang ada di bawah ini: 
Tabel 1. Daftar Data UMKM Di Kelurahan Purus Kecamatan Padang Barat Tahun 2015-2018

\begin{tabular}{|l|l|l|l|l|l|}
\hline \multirow{2}{*}{ No } & \multirow{2}{*}{$\begin{array}{c}\text { Bentuk } \\
\text { Usaha }\end{array}$} & \multicolumn{3}{|c|}{$\begin{array}{c}\text { Jumlah UMKM dalam } \\
\text { Kawan Kelurahan }\end{array}$} \\
\cline { 3 - 6 } & $\mathbf{2 0 1 5}$ & $\mathbf{2 0 1 6}$ & $\mathbf{2 0 1 7}$ & $\mathbf{2 0 1 8}$ \\
\hline 1. & Kuliner & 2 & 7 & 13 & 19 \\
\hline 2. & IMR & 5 & 2 & 7 & 10 \\
\hline 3. & IKT & 2 & 2 & 4 & 3 \\
\hline 4. & Dagang & 7 & 7 & 5 & 18 \\
\hline 5. & Jasa & 2 & 2 & 0 & 2 \\
\hline 6. & PKL & 2 & 0 & 1 & 1 \\
\hline \multicolumn{2}{|r|}{ Total } & $\mathbf{2 0}$ & $\mathbf{2 0}$ & $\mathbf{2 0}$ & $\mathbf{5 3}$ \\
\hline
\end{tabular}

Sumber: Dinas Koperasi dan UMKM Kota Padang (diolah)

\section{Catatan:}

IMR : Industri Makanan Ringan

IKT : Industri Kerajinan Tangan

PKL : Pedagang Kaki Lima

Berdasarkan data yang diperoleh di Dinas Koperasi dan UMKM Kota Padang diketahui bahwa tingkat jumlah UMKM Kota Padang sempat mengalami kenaikan yaitu pada tahun 2018 sebesar 53 UMKM yang dilatih langsung oleh Dinas Koperasi dan UMKM .

Walaupun terjadi peningkatan secara kuantitatif, namun hal tersebut tidak menjadi sebuah bagian program utama dari Dinas Koperasi dan UMKM Kota Padang. Hal itu dikarenakan Dinas Koperasi dan UKM lebih memprioritaskan kualitas supaya mampu memiliki peran penting ketika menuntaskan pengangguran dan kemiskinan di Kota Padang.

Dilakukannya pengembangan sektor UKM di Kota Padang menjadi hal yang wajib untuk dilakukan. Hal itu dikarenakan kondisi yang terjadi saat sekarang ini membuat sektor UKM bisa membuka lahan/lowongan pekerjaan untuk pekerja yang masih belum ditampung di dunia kerja. Kemudian sektor UKM pun dapat memberi kontribusi yang signifikan untuk keuntungan PAD (Pendapatan Asli
Daerah). Oleh karena itu tugas yang utama dari Dinas Koperasi dan UMKM Kota Padang ialah melakukan otonomi daerah dalam melakukan semua tugas membantu yang telah diberikan oleh pemerintah pusat maupun dari pemerintah provinsi. Adapun konsekuensi dari kegaitan tersebut, Dinas Koperasi dan UMKM wajib melaksanakan segala program kegiatan yang memiliki tujuan meningkatkan potensi sektor UKM terutama di Kelurahan Purus Kota Padang.

\section{TINJAUAN PUSTAKA \\ Konsep Efektifitas}

Pengertian dari efektivitas ialah suatu hal yang bisa dilakukan seseorang dalam melaksanakan tugas (misi atau operasi kegiatan program) yang berasal dari sebuah organisasi dan sejenisnya tanpa adanya menggunakan ketegangan atau tekanan dalam kegiatan pelaksanaannya (Kurniawan, 2005).

Menurut Mahmudi efektivitas menjadi sebuah relasi antara hasil dan sasaran, dimana lebih meningkat partisipasi hasil terhadap perolehan sasaran dan lebih meningkatkan keberhasilan dari lembaga (Mahmudi., 2005).

Sedangkan pendapat para ahli memiliki pendapat efektivitas sebagai sebuah konseptual yang memiliki urgensi yang mampu memberi sebuah deskripsi yang berkaitan dengan keberhasilan sebuah organisasi dalam meraih tujuan atau sasarannya, dan dapat diartikan juga bahwa efektivitas ialah ukuran seberapa besar tingkat pencapaian tujuan dari segala kegiatan yang telah dilakukan dan dibanding dengan sasaran yang telah ditentukan sebelumnya.

\section{Indikator Efektivitas}

Siagian (2001:32-35) berpendapat bahwa dalam mengukur tingkat efektivitas, terdapat 8 indikator yang perlu diperhatikan yakni seperti dibawah ini:

1. Kejelasan arah yang akan diraih. Jika pada pemikiran anggota organisasi sudah ada keyakinan dan kesadaran yang mantap bahwa dengan dicapainya 
sebuah tujuan organisasi pada hakikatnya berarti tercapai tujuantujuan masing masing induivu maka ketika proses dalam mencapai sasaran akan lebih lancar, tertib, dan efektif.

2. Kejelasan strategi pencapaian tujuan. Hal ini bisa diketahui dengan pengertian dari strategi yakni untuk melaksanakan berbagai upaya guna tercapainya sasaran yang disusun harus mengetahui“jalan" yang diikuti supaya para implementor tidak salah memilih cara dalam mencapai tujuan organisasi.

3. Teknik analisa serta merumus kebijakan yang mantap. Hal ini terkait dengan apa tujuan yang ingin diraih serta pendekatan apa yang telah ditetapkan, artinya prosedur yang dikeluarkan harus dapat menjembatani tujuan pada cara penerapan kegiatan operasional.

4. Kemampuan untuk merumuskan sebuah pembuatan rencana yang matang, dimana untuk mengetahui efektivitasnya dapat diketahui dilihat sejauh apa sebuah organisasi tertentu mampu untuk: 1) Menerka keadaan yang sedang dihadapi. 2) Membuat dan memilih untuk menghadapi masa depan yang akan dialami. 3) mengembangkan setiap unsur yang mengarah ke masa depan. 4) Bisa memperhitungkan faktor yang membatasi yang dicurigai akan dialami dalam berbagai aspek dalm kehidupan berorganisasi. 5) Bisa menghitung situasi dan kondisi lingkungan yang akan muncul.

5. Dalam menyusun sebuah program yang tepat maka diperlukan penjabaran program-program kegiatan yang tepat, dikarenakan jika tidak terjadi maka kegiatan yang dilakukan kurang mempunyai panduan pada bertindak serta bekerja.

6. Tersedianya sarana dan prasarana. Salah satu faktor efektivitas di organisasi ialah keahlian dalam bertindak secara baik.

7. Dalam melakukan tugas secara efektif dan efesien. Maka perlu adanya tujuan yang jelas, proses yang efektif, strategi yang tepat, tepatnya pemaparan persiapan saat program matangnya rencana, dan dalam terbatasnya sarana dan prasarana keahlian dalam memilih hal tersebut dikarenakan masih harus dipakai pada operasional yang efektif serta efesien.

8. Bentuk pemeriksaan dan penanganan wajib memiliki sifat yang mendidik dengan ketentuan beberapa ciri ciri, yaitu sebagai berikut: 1) Pengendalian dan pengawasan yang lebih mengutamakan cara yang bersifat melindungi daripada usaha yang bersifat represif. 2) Pengendalian dan pengawasan tidak hanya mencari "siapa yang salah" namun juga terdapat beberapa hal yang diperlukan untuk penyempurnaan dalam sistem bekerja di sebuah organisasi. 3) Apabila muncul penyimpangan, maka tindakan yang korektif yang harus dilaksanakan adalah melakukan segala hal yang bersifat edukatif selama masih dapat dipertanggung jawabkan. 4) Objektifitas ketika melakukan segala pengendalian dan pengawasan hanya bisa dipertahankan saja apabila prosedur, standar kerja, serta karakteristik prestasi sudah pasti diketahui oleh pihak pengawas maupun pihak yang diawasi. 5)Pengendalian dan pengawasan yang memiliki sifat obyektif dan edukatif belum berarti tindakan indisipliner tidak diambil sebagai tindakan.

\section{Konsep Peran}

Peran menurut pandangan Soerjono Soekanto (dalam saputra, 2016) mengatakan peran ialah segala hal yang dinamis kedudukannya (status), jika individu menggunakan hak dan kewajiban sesuai dengan jabatannya, maka dapat dikatakan bahwa ia telah terjalannya sebuah peranan didalam dirinya.

Peran dalam pandangan Miftah Thoha (dalam Taranggana Gani Putra, 2015:03) mengatakan bahwa peran sebagai sekumpulan perilaku yang dapat memberi 
harapan untuk dilakukan oleh seseorang. Penghargaan yang dimaksud ialah ebuah norma yang dapat memberi akibat terjadinya sebuah peranan.

Berdasarkan beberapa pendapat yang telah diuraikan bisa diketahui peran merupakan sebuah rangkaian perilaku yang diinginkan oleh seseorang terhadap orang lain yang berguna bagi struktur sosial di masyarakat dan bisa sesuai dengan kedudukan bagi suatu jabatan tersebut.

\section{Konsep Pengembangan}

Menurut Taranggana Gani Putra (2015:05) dalam Amin Widjaja Tunggala yang mengutip Dani Danuar Tri mengatakan bahwa pengembangan ialah sebuah usaha yang dikerjakan organisasi guna memperbaharui implementasi dari pekerjaan yang mengarah kepada keahlian yang mengembangkan kemampuan daya tanggap organisasi kepada lingkungan guna meraih efektifitas dan efesiensi.

$$
\text { Malayu S.P. Hasibuan ( d a la m }
$$

Karthag o, 2014 ) mengatakan bahwa pengembangan ialah proses dalam meningkatkan keterampilan teoritis, teknis, pemikiran dan moral karyawan dengan metode latihan dan pendidikan.

Berdasarkan beberapa pendapat yang telah dijelaskan dapat diketahui pengembangan ialah sebuah kegiatan yang berguna untuk mengatur ulang kegiatan yang dilaksanakan dari keahlian karyawan dengan mengembangkan daya tanggap organisasi kepada wilayah sekitar duna meraih efektifitas dan efisiensi seorang karyawan.

\section{METODE PENELITIAN}

Pada penelitian ini cara yang dipakai ialah metode kualitatif dan tempat meneliti adalah di Kantor Dinas Koperasi dan UKM Kota Padang. Penelitian ini meneliti kendala dan upaya yang dihadapi di Kantor Dinas Koperasi dan UKM Kota Padang. Dalam mengumpulkan data dengan sistem wawancara, observasi dan studi dokumentasi. Sedangkan pada pengujian keabsahan datanya dilakukan dengan menggunakan metode triangulasi sumber. Teknik menganalisis data dengan cara proses mencari, mengatur wawancara dan mengumpulkan informasi dilapangan serta data lain yang telah dikumpulkan sehingga dapat merumuskan sehingga dapat merumuskan hasil temuan. Dimulai dari pengumpulan data, reduksi, pengadaan data, serta penarikan determinasi.

\section{HASIL DAN PEMBAHASAN \\ Efektivitas Peran Dinas Koperasi dan UMKM Kota Padang Dalam Pengembangan Usaha Kecil Dan Menengah Di Kelurahan Purus Kota Padang}

Pelaksanaan peran Dinas Koperasi dan UMKM Kota Padang dalam pengembangan UMKM dikelurahan purus dalam penelitian ini terdiri dari delapan program yaitu: kepastian tujuan yang akan dicapai, kepastian strategi dalam menggapai sasaran, proses analisis dan perumusan kebijakan yang kukuh, keahlian dalam menyusun perencanaan yang terperinci, penyusunan program yang benar, tersedianya sarana dan prasarana, implementasi tugas secara efektif dan efesien, sistem pengendalian dan pengawasan yang bersifat mendidik. Mengacu pada pengertian efektivitas menurut Kurniawan (2005:109) yang mengatakan bahwa efektivitas ialah keahlian dalam menyelesaikan tugas, fungsi (operasi pelaksanaan misi ataupun program) di sebuah organisasi dan sejenisnya dengan tidak terdapatnya ketegangan atau tekanan dalam proses pelaksanaannya.

Dalam mengimplementasikan sebuah peran, Dinas Koperasi dan UMKM Kota Padang menjalankan perannya dalam pengembangan UMKM di Kelurahan Purus Kota Padang melalui strategi yang terhubung dengan arah kebijakannya berdasarkan rencana strategis Dinas Koperasi dan UMKM Kota Padang tahun 2019-2024 meliputi: a)Perkuatan perdampingan dan koordinasi penguatan usaha mikro, b) perkuatan fasilitasi promosi 
dan pemasaran produk. c)perkuatan fasilitasi diversifikasi usaha mikro dan pengembangan ekonomi kreatif, d)meningkatkan kapasitas sistem pendukung usaha yang ada (UPTD dana bergulir dan pendamping usaha mikro).

Pada hasil penelitian yang dilakukan oleh penulis di Dinas Koperasi dan UMKM Kota Padang, menyebutkan efektivitas peran Dinas Koperasi dan UMKM Kota Padang dalam upaya meningkatkan kualitas usaha kecil dan menengah di Kelurahan Purus Kota Padang sudah menjalankan perannya terhadap pelaku UMKM dengan memberikan pelatihan, Pembinaan kepada pelaku UMKM tetapi hal masih belum sesuai dengan keinginan dari si pelaku UMKM yakni memberikan pelatihan pemasaran dan pengemasan sesering mungkin untuk dapat membantu pelaku UMKM mengembangkan usahanya.

Pelaksanaan pengembangan UMKM di kelurahan purus secara administratif dikelola oleh Dinas Koperasi dan UMKM Kota Padang saat ini masih berpedoman pada rencana strategis dari Dinas Koperasi dan UMKM Kota Padang Tahun 20192024. Namun berdasarkan tupoksi pada setiap unit kerja pada Dinas Koperasi dan UMKM Kota Padang, pedoman yang digunakan untuk bisa mengembangkan UMKM belum cukup efektif pelaksanaan kegiatan pengembangan UMKM tersebut.

Pada hakekatnya peran Dinas Koperasi dan UMKM Kota Padang merupakan tindakan untuk memberikan pelatihan, pembinaan kepada pelaku UMKM dengan tujuan agar bisa membantu pelaku UMKM mengembangkan usaha ke masyarakat yang lebih luas. Maksudnya peran Dinas Koperasi dan UMKM Kota Padang bertujuan untuk mengetahui para pelaku UMKM sudah bisa mengembangkan usaha yang ada di kelurahan purus.

Secara umum pedoman yang digunakan oleh Dinas Koperasi dan UMKM Kota Padang yang dalam pelaksanaan administrasinya yang dikerjakan oleh Dinas Koperasi dan UMKM Kota Padang dalam kegiatan pelatihan dan pembinaan kepada UMKM adalah Undang-undang No. 25 tahun 1992 tentang Perkoperasian, Undangundang No. 20 tahun 2008 tentang UMKM, Undang-undang No. 23 tahun 2014 tentang pemerintah daerah, Peraturan daerah Kota Padang No. 20 tahun 2012 tentang pemberdayaan Usaha Mikro, kecil dan menengah, DPA-SKPD Dinas Koperasi dan UMKM Kota Padang tahun anggaran 2020. Apabila dikaji, peraturan-peraturan ini sudah cukup mampu menpedomani pelaksanaan pengembangan UMKM sehingga berjalan efektif.

Kinerja usaha UMKM dapat meningkat dengan adanya pengembangan ini dan juga mampu bersiap dalam menghadapi persaingan usaha. Pengembangan yang dibantu berupa kebijakan pemerintah untuk mengembangkan usaha mikro, kecil maupun menegah. Menurut (Siagian, 2001:32-35) memberikan beberapa indikator untuk mengukur efektivitas yang meliputi:

a) Kejelasan tujuan yang hendak dicapai.

Adapun kepastian tujuan yang hendak diraih dimaksudkan ialah memberikan pelatihan dalam bentuk keterampilan mengemaskan produk, promosi produk yang akan diberikan kepada pelaku UMKM. Namun mengenai pelatihan ini belum sepenuhnya maksimal diberikan oleh Dinas Koperasi dan UMKM Kota Padang dan tenaga pendamping UMKM untuk pelaku UMKM. Dari hasil penelitian yang dikerjakan di lapangan oleh penulis dapat dipahami bahwa Dinas Koperasi dan UMKM Kota Padang belum maksimal melakukan pelatihan dalam membina para pelaku UMKM tersebut. Karena sebagian besar dari pelaku UMKM ini sudah mendapatkan pelatihan pembinaan tetapi tidak sesering mungkin diadakan pelatihan untuk pelaku UMKM tersebut. Juga dari pembinaan yang mereka rasakan 
tidak sesuai karena pelaku UMKM tidak diajarkan pelatihan dalam bentuk pengemasan dan pemasaran produk.

b) Kejelasan strategi pencapaian tujuan. untuk bisa mencapai tujuan kejelasan strategi, Dinas Koperasi dan UMKM Kota Padang selalu membantu pelaku UMKM yang membutuhkan standarisasi mutu produk, membutuhkan bantuan biaya dan memberikan pelatihan pembinaan kepada pelaku UMKM. Maka Dinas Koperasi dan UMKM Kota Padang selaku pihak dari pemerintah membantu pelaku UMKM untuk bisa mengembangkan usaha. Sedangkan dalam hasil penelitian yang dikerjakan di lapangan oleh penulis dapat dipahami bahwa Dinas Koperasi dan UMKM Kota Padang telah memberikan bantuan kepada pelaku UMKM untuk mengembangkan usaha. Meskipun Dinas Koperasi dan UMKM Kota Padang tidak semuanya bisa dibantu oleh Dinas Koperasi dan UMKM Kota Padang, tetapi Dinas Koperasi dan UMKM Kota Padang dapat melaksanakan perannya dengan cara memberikan pelaku UMKM tersebut standarisasi mutu produk, pembiayaan dan pelatihan pembinaan yang diadakan.

c) Sistem Analis Dan Perumusan prosedur yang Aman.

Pada tahun 2020 Dinas Koperasi dan UMKM Kota Padang pada tahun menargetkan Rumah Tangga Miskin Produktif (RTMP) yang akan menentukan pelaku UMKM ini untuk dapat memenuhi kebutuhan sehari-hari yang tercukupi dan mengatasi kemiskinan. Untuk dapat membantu pelaku UMKM tersebut Dinas Koperasi dan UMKM Kota Padang membantu pelaku UMKM dari segi pemasaran, permodalan, standarisasi mutu produk maupun dari segi Diversifikasi Usaha untuk mempermudah pelaku UMKM dalam mengembangkan usaha. Sedangkan dalam hasil penelitian yang dikerjakan di lapangan oleh penulis dapat dipahami bahwa Dinas Koperasi dan UMKM Kota Padang setidaknya memberi kemudahan kepada setiap pelaku UMKM dalam mengembangkan usaha, sebab tidak semuanya bisa difasilitasi oleh Dinas Koperasi dan UMKM Kota Padang.

d) Keahlian dalam menyusun perencanaan yang benar.

dalam melaksanakan pembuatan rencana yang matang dibutuhkan untuk membantu pelaku UMKM dalam meningkatkan mutu usaha, Dinas Koperasi dan UMKM Kota Padang melalui tenaga pendamping UMKM selalu membina dan mengarahkan pelaku UMKM untuk bisa mengembangkan produk yang dihasilkan pelaku UMKM. Dengan diadakan perencanaan dalam proses pengembangan bisa terangkum seluruhnya secara terstuktur, sistematis dan bermanfaat untuk pelaku UMKM. Sedangkan dalam hasil penelitian yang dikerjakan di lapangan oleh penulis dapat dipahami bahwa Dinas Koperasi dan UMKM Kota Padang sudah memberikan bantuan kepada setiap pelaku UMKM dalam pembinaan dan pengarahan melalui tenaga pendamping UMKM. Namun diharapkan pelaku UMKM ini bisa dibina dan diarahkan oleh Dinas Koperasi dan UMKM Kota Padang.

e) Penyusunan program yang tepat. sebagai pihak yang terlibat dalam membantu pelaku UMKM dalam meningkatkan mutu usaha, Dinas Koperasi dan UMKM Kota Padang memfokuskan penyusunan program seperti dari segi permodalan, segi pemasarannya dan standari mutu produk dan segi diversifikasi usaha untuk mempermudah pelaku UMKM dalam mengembangkan usahanya. 
Untuk mempermudah pelaku UMKM dalam mengembangkan usaha, maka Dinas Koperasi dan UMKM Kota Padang selaku pihak pemerintah membantu pelaku UMKM untuk bisa memberikan edukasi melalui pelatihan-pelatihan kepada pelaku UMKM. Sedangkan dalam hasil penelitian yang dikerjakan di lapangan oleh penulis dapat dipahami bahwa Dinas Koperasi dan UMKM Kota Padang telah membantu UMKM dalam memberikan edukasi melalui pelatihan kepada pelaku UMKM.

f) Tersedianya sarana dan prasarana. supaya bisa memfasilitasi pelaku UMKM dari segi bidang sarana dan prasarana, Dinas Koperasi dan UMKM Kota Padang bekerjasama dengan anggota dewan perwakilan rakyat (DPR) untuk meminta bantuan aggaran modal untuk pelaku UMKM. Dinas Koperasi dan UMKM Kota Padang selalu membantu berupa peralatan yang dibutuhkan para pelaku UMKM dan bisa bermanfaat secara baik oleh pelaku UMKM meskipun belum semua UMKM yang mendapatkannya namum hanya tempat usaha yang baru bisa diberikan kepada pelaku UMKM. Sedangkan dalam hasil penelitian yang dikerjakan di lapangan oleh penulis dapat dipahami bahwa Dinas Koperasi dan UMKM Kota Padang telah membantu UMKM dalam memberikan sarana dan prasarana bekerjasama dengan anggota Dewan Perwakilan Rakyat (DPR) untuk meminta bantuan aggaran modal untuk pelaku UMKM.

g) Pelaksanaan tugas secara efektif dan efisien. agar pengembangan UMKM Kelurahan Purus berjalan lancar, maka pekerjaan yang efektif dan efisien sangat dibutuhkan. Dinas Koperasi dan UMKM Kota Padang melakukan pengecekkan terhadap fasilitas pelaku UMKM yang masih tidak bersih, penertiban UMKM yang masih berdiri di diatas fasilitas umum kota seperti berjualan di trotoar pejalan kakai, serta memberikan edukasi pemasaran produk secara online selama empat hari. Sedangkan dalam hasil penelitian yang dikerjakan di lapangan oleh penulis dapat dipahami bahwa Dinas Koperasi dan UMKM Kota Padang melaksanakan tugasnya secara efektif dan efesien seperti pengecekkan terhadap fasilitas pelaku UMKM yang masih tidak bersih, penertiban UMKM yang masih berdiri di diatas fasilitas umum.

h) Sistem pemeriksaan dan pengendalian yang bersifat mendidik.

Pada aspek pengendalian dan pengawasan dalam pengembangan UMKM di kelurahan purus dilakukan dengan memperbaiki produk yang dihasilkan oleh pelaku UMKM serta mengatur posisi berjualannya para pelaku UMKM ke tempat yang ramai dan bersih. Namun tenaga pendamping UMKM yang mendukung Dinas Koperasi dan UMKM Kota Padang dalam proses evaluasi dan monitoring dan memberikan laporan dari hasil pengawasan dan pengamatannya. Sedangkan dalam hasil penelitian yang dikerjakan di lapangan oleh penulis dapat dipahami bahwa Dinas Koperasi dan UMKM Kota Padang melalui tenaga pendamping UMKM melakukan evaluasi dan monitoring dan memberikan laporan dari hasil pengawasan dan pengamatan untut pelaku UMKM. 
Kendala Efektifitas Peran Dinas Koperasi dan UMKM Kota Padang dalam Pengembangan UMKM Di kelurahan Purus Kota Padang

Berdasarkan uraian pembahasan diatas mengenai pengembangan UMKM oleh Dinas Koperasi dan UMKM Kota Padang, dapat penulis simpulkan bahwa dalam penerapannya terdapat kendala-kendala yang kemudian mengganggu proses pengembangan tersebut.

Sedangkan dalam hasil penelitian yang dikerjakan di lapangan oleh penulis dapat diketahui bahwa kendala-kendala dalam pengembangan UMKM oleh Dinas Koperasi dan UMKM Kota Padang, yaitu:

\section{Kendala Internal}

Menurut Gow dan Mors dalam Pasolong (2010:59), kendala internal (Internal Constraint) adalah faktor pembatas antara organisasi dengan sistem yang asalnya dari dalam organisasi itu sendiri. Sedangkan dalam hasil penelitian yang dikerjakan di lapangan oleh penulis dengan informan penelitian, ternyata ada kendala internal dalam pengembangan UMKM oleh Dinas Koperasi dan UMKM Kota Padang adalah Dinas Koperasi dan UMKM Kota Padang perlu anggaran lebih besar untuk melakukan pengembangan UMKM Seperti tahun sebelumnya ketika pemberian sarana dan prasarana kepada pelaku UMKM itu tidak semua UMKM mendapatkan bantuan untuk pihak kelurahan dari sarana dan prasarana.

2. Kendala Eksternal

Menurut Gow dan Mors dalam

Pasolong (2010:59) kendala

eksternal (External Constraint) adalah faktor pembatas organisasi yang asalnya dari luar organisasi atau luar sistem. Sedangkan dalam hasil penelitian yang dikerjakan di lapangan oleh penulis dengan informan penelitian, ternyata ada kendala eksternal dalam pengembangan UMKM oleh Dinas
Koperasi dan UMKM Kota Padang adalah sesuatu yang tidak bisa jangkau atau awasi itu yang kendala yang terjadi dari luar. Pada saat ini masalah pandemi covid itu termasuk kendala eksternal diluar dari perencanaan pengembangan umkm. Salah satu dampaknya daya beli konsumen tersebut turun drastis.

Jadi dapat dipahami bahwa dalam pengembangan UMKM oleh Dinas Koperasi dan UMKM Kota Padang ada kendala, baik itu kendala yang datang dari dalam (internal) atauoun itu berasal kendala yang datang dari luar (eksternal). begitu juga saat proses pengembangan tersebut.

Upaya Dari Kendala Efektifitas Peran Dinas Koperasi dan UMKM Kota Padang dalam Pengembangan UMKM Di Kelurahan Purus

Berdasarkan hasil penelitian yang dikerjakan di lapangan oleh penulis, ada beberapa hal yang bisa dilakukan guna menangani kendala yang dihadapi dalam pengembangan UMKM oleh Dinas Koperasi dan UMKM Kota Padang adalah seperti dibawah ini:

Upaya yang dilakukan harus berdasarkan tupoksi untuk bisa memfasilitasi UMKM dengan menjalin banyak kerjasama dengan dinas-dinas yang terkait gunanya untuk standarisasi mutu produk dengan pihak BUMN, mencari tahu bagaimana cara mendapatkan CSR, dan Mencari tahu bagaimana cara mendapatkan dana hibah baik dari tingkat kementrian, provinsi, kota, atau perusahaan swasta.

Upaya lainnya adalah dari segi pemasaran kita juga sudah melakukan kerjasama dengan mini market, dengan media online Dinas Koperasi dan UMKM Kota Padang sudah melakukan upaya tersebut. Hanya saja upaya tersebut harus didukung oleh kedua belah pihak antara pihak Dinas Koperasi dan UMKM Kota Padang. 


\section{PENUTUP}

Hasil ketika menganalis data yang telah penulis lakukan terhadap informasi ini bertujuan menjawab permasalahan penelitian yang berhubungan dengan efektivitas peran Dinas Koperasi dan UMKM Kota Padang dalam pengembangan usaha kecil dan menengah di kelurahan purus Kota Padang.

Hasil penelitian menunjukkan kondisi di mana Dinas Koperasi dan UMKM Kota Padang telah menjalankan perannya cukup bagus dengan diberikan pelatihan pembinaan pada pelaku UMKM yang dilaksanakan Dinas Koperasi Dan UMKM Kota Padang. Pelaksanaan Efetivitas peran Dinas Koperasi dan UMKM Kota Padang dalam pengembangan UMKM pada Dinas Koperasi dan UMKM Kota Padang pada setiap pelaksanaan pengembangan dalam melakukan tujuan yang ingin dicapai sudah terlaksana tetapi dengan yang diinginkan masih belum sesuai dengan keinginan pelaku UMKM yaitu dengan memberikan pelatihan pemasaran dan pengemasan sesering mungkin untuk pelaku UMKM.

Dinas Koperasi dan UMKM Kota Padang telah berusaha membantu pelaku UMKM untuk bisa mengembangkan usaha dari pelaku UMKM tersebut walaupun tidak semuanya bisa difasilitasi oleh pihak Dinas Koperasi dan UMKM Kota Padang. Dinas Koperasi dan UMKM Kota Padang sudah mendampingi pelaku UMKM dalam pembinaan dan pengarahan walaupun pelaku UMKM tersebut sebagian tidak mau dibina dan diarahkan oleh Dinas Koperasi dan UMKM Kota Padang.

Kendala yang dialami oleh Dinas Koperasi dan UMKM Kota Padang adalah anggaran Dinas Koperasi dan UMKM Kota Padang perlu anggaran lebih besar untuk melakukan pengembangan UMKM. Seperti tahun sebelumnya ketika pemberian sarana dan prasarana kepada pelaku usaha UMKM itu tidak semua UMKM mendapatkan bantuan untuk pihak kelurahan dari sarana dan prasarana. Sedangkan kendala eksternal, sesuatu yang tidak bisa dijangkau atau diawasi. Kendala seperti itu yang terjadi dari luar seperti masalah pandemi covid-19 yang berdampak kepada daya beli konsumen yang turun drastis.

Mengenai hasil yang diperoleh pada penelitian yang telah diteliti, saran yang bisa berikan oleh peneliti, yaitu:

1. Mengenai tentang pengembangan UMKM ini, diharapkan Dinas Koperasi dan UMKM Kota Padang dapat lebih memaksimalkan dalam memberikan sosialisasi kepada semua pelaku usaha mengenai perlunya mendapatkan pelatihan pembinaan supaya usahanya berkembang lagi.

2. Diharapkan Dinas Koperasi dan UMKM Kota Padang saat meningkatkan produktivitas para pelaku usaha UMKM dapat diberi bantuan.

3. Dinas Koperasi dan UMKM Kota Padang diharapkan memiliki galeri supaya dapat mempromosikan produk hasil UMKM.

4. Dinas Koperasi dan UMKM Kota Padang harus sering diadakan pelatihan pembinaan untuk memajukan usaha para pelaku usaha UMKM.

5. Diharapkan Dinas Koperasi dan UMKM Kota Padang menyediakan lebih banyak tenaga profesional untuk dapat mempermudah pelaku usaha dalam pelatihan pembinaan kepada pelaku usaha UMKM.

\section{DAFTAR KEPUSTAKAAN}

Karthago, A. H. (2014). Peran Dinas Kebudayaan dan Pariwisata dalam pengembangan seni budaya di Kabupaten Bukungan. Jurnal Ilmu Pemerintahan, 2(1), 1995-2007.

Kurniawan, F. D, D. (2014). Pemberdayaan Usaha Mikro Kecil dan Menengah (UMKM) dalam Penanggulangan Kemiskinan. Jurnal Kebijakan Dan Manajemen Publik (JKMP)., 2, 103220.

Kurniawan, A. (2005). Transformasi Pelayanan Publik. Grafindo Persada. 
Mahmudi. (2005). Manajemen Kinerja Sektor Publik. UPP AMP YKPN.

Pasolong, H. (2010). Teori Administrasi Negara. Alfabeta.

Putra, T. G. (2015). Peran Pemerintah Daerah dan Partisipasi Pelaku Usaha dalam Pengembangan UMKM ManikManik Kaca di Kabupaten Jombang. Jurnal Kebijakan Dan Manajemen Publik, 3, 1-10.

Siagian, S. P. (2001). Manajemen Sumber Daya Manusia. PT. Bumi Aksara.

Tiara, R., \& Mardianto. (2019). Demography Journal of Sriwijaya ( DeJos ) Efektivitas Program Bantuan Pangan Non Tunai ( BPNT ). 37-46. 